\title{
Séfora: a mulher proativa que livra 0 homem da morte (Ex 4,24-26)
}

\section{Zipporah: the proactive woman who frees man from death (Ex 4,24-26)}

Leonardo Agostini Fernandes*

Resumo: Na dinâmica das tradições do antigo Israel, sobre o êxodo do Egito e no contexto da vocação e missão de Moisés, esse episódio destaca, não obstante a sua difícil compreensão, o importante protagonismo de Séfora e, por ela, da atuação singular de uma mulher na Bíblia. E isso já vale o seu estudo. A abordagem realizada neste artigo privilegia a análise narrativa, pois esta permite encontrar novos elementos para a compreensão que vão muito além da abordagem diacrônica. Esta é a finalidade do presente artigo, visando elucidar pontos importantes para a ação sócio-pastoral.

Palavras-chave: Antigo Testamento, Dinâmica do Êxodo, Feminino na Bíblia, Hermenêutica, Libertação.

Abstract: In the dynamics of Israel's ancient traditions about the exodus from Egypt and in the context of Moses's vocation and mission, this episode highlights, notwithstanding its difficult comprehension, the important role of Zipporah and, through her, the singular role of a woman in the Bible. And this study is really worth regarding. The approach employed in this paper emphasizes the narrative analysis that allows the identification of new elements whose understanding is beyond a diachronic approach. This is the main purpose of this paper aiming at elucidating important points for socio-pastoral action.

* Doutor em Teologia Bíblica pela Pontifícia Universidade Gregoriana de Roma. Diretor e docente do Departamento de Teologia da PUC-Rio. E-mail: kyriou33@yahoo.it 
Keywords: Old Testament, Dynamics of Exodus, Female in the Bible, Hermeneutic, Liberation.

\section{Introdução}

A libertação dos filhos de Israel do Egito, pelas mãos de Moisés, segundo a tradição bíblica, ${ }^{1}$ não aconteceu sem a direta participação de mulheres, as quais desempenham uma ação direta na vida de futuro mediador: a mãe, a irmã, a filha do Faraó (cf. Ex 2,1-13) e Séfora, a esposa que prolonga e continua a série das mediações femininas contra a maldade de certos homens. ${ }^{2}$ Já Ex 1,15-21 havia introduzido, no livro do Êxodo, o papel das parteiras que, por temor a Deus, desobedeceram ao Faraó e lutaram por impedir a morte dos inocentes. Por meio dessas mulheres, a tradição do antigo Israel procurou acentuar a decisiva importância do protagonismo feminino na realização dos desígnios salvíficos de Deus.

Ex 4,24-26 já foi motivo de inúmeros estudos e todos afirmam de que se trata de um episódio enigmático, misterioso e com explicações pouco satisfatórias. ${ }^{3}$ A base para os problemas, do ponto de vista textual, encontra-se na dificuldade de atribuição de sujeitos aos sufixos pronominais. ${ }^{4}$ Além disso, YHWH, que havia feito de tudo para convencer Moisés a regressar ao Egito e aceitar uma missão libertadora, se coloca como "inimigo" do seu eleito libertador; mas, além disso, ocorre perceber que nas mãos da mulher de Moisés esteve a solução!

Além da razão ou dos motivos (narratológico, teológico e cultual), esse episódio ajuda a compreender o papel da mulher em todo

\footnotetext{
1 "En el relato de la liberación unido a la figura de Moisés se hallan incluidas todas las opresiones y experiencias de liberación israelita, desde la esclavitud en Egipto pasando por la regencia de Salomón hasta el imperialismo asirio y babilónico. Moisés mismo se convierte en este contexto en una figura que supera todo lo que jamás apareció en Israel en funcionarios públicos. Solo una cosa no es Moisés: rey” (KESSLER, 2013, p. 360-361).

2 Cf. SILVA, 2004, p. 36-37.

3 Cf. RÖMER, 1994, p. 6-7; PRIOTTO, 2014, p. 112-113.

4 Sobre os problemas específicos de Ex 4,24-26, Childs (2003, pp. 126-131) faz uma apresentação quase que exaustiva, levantando inúmeras questões que permitem avançar com a pesquisa em diversas direções.
} 
o processo de libertação dos filhos de Israel do Egito e ao longo da história religiosa do antigo Israel. A lógica a ser encontrada está além dos problemas textuais que as versões antigas tentaram minimizar ou os estudos realizados procuram apontar no texto.

Por certo, esses não vão ignorados, mas não devem ser priorizados. Talvez, a suposta falta de sentido seja a real lógica do texto! Ou se não existe essa lógica, ela ainda pode ser buscada nos desígnios de Deus que, por certo, são possuidores de uma lógica que transcende o ordinário da existência humana. ${ }^{5}$ É certo, também, que a história da interpretação, judaico-cristã ${ }^{6}$ e histórico-crítica, continua influenciando os novos estudos, algo inevitável inclusive neste artigo, porque a justa distância assumida é um tênue fio com uma justa aproximação ao que já foi dito.

O presente estudo está articulado em sete partes: contextualização, delimitação, tradução do texto em hebraico, estrutura do texto e da narrativa, comentário ao texto e considerações finais, propondo não uma solução para o mistério, que deve permanecer mistério, mas a possibilidade da atualização da mensagem que condiz com o mistério.

\section{Contexto}

\subsection{Contextualização do episódio}

Ex 4,24-26 não possui claras conexões com os textos precedentes ou subsequentes. ${ }^{7}$ Poderia ser a continuação lógica da primeira parte

\footnotetext{
5 Cf. FANULI, 1994, p. 39.

6 É certo que o cristianismo continuou interpretando a Bíblia como um todo, segundo a centralidade da leitura cristológica (descontinuidade), mas não deixou de se apropriar dos válidos métodos judaicos (continuidade), pois para fundamentar muitas das suas afirmações, necessitou manter e não apagar a interpretação judaica das suas Escrituras Sagradas, que continham as promessas a serem realizadas (Gl 4,4; Hb 1,1-4). Com isso, as interpretações judaicas foram cristianizadas em muitos sentidos, sem que se perdesse a sua leitura e compreensão judaicas, mas alcançando novas compreensões (JACOBS, 2008, p. 332).

7 Cf. CHILDS, 2003, p. 126. É comum admitir que Ex 4,24-26 e Gn 32,23-31 possuam traços paralelos (FANULI, 1994, p. 46-47; NEPI, 2002, p. 132), considerando, inclusive, que Ex 4,24-26 é dependente de Gn 32,23-31(RÖMER, 1994, p. 5).
} 
Ano XXIIl • № $86 \cdot$ Jul/Dez 2015

de Ex 3,20, ou poderia se estabelecer, igualmente, uma ligação com a declaração que Moisés teria que dizer ao Faraó (embora não tenha dito), anunciando que Israel tinha que deixar o Egito porque é o seu filho primogênito. Se isto não acontecesse, YHWH feriria de morte o filho do Faraó (Ex 4,22-23).

Neste sentido, o filho de Moisés circuncidado, seja o seu primogênito (Gersam) ou o seu "segundogênito" (Eliezer), antecipa a ameaça dirigida ao Faraó e a ação libertadora ocorrida na noite de páscoa. ${ }^{8}$ A obediência exigida por Moisés ao Faraó corresponderia ao gesto sacrifical de Séfora, realizado através do ritual da circuncisão. Surge uma primeira conclusão: se YHWH não fez questão de poupar Moisés e sua família de uma ameaça de morte, por que pouparia o Faraó e sua família?

Uma compreensão e interpretação satisfatórias tornam-se o desafio para qualquer estudioso. Mais importante que o significado histórico, sem negá-lo, é buscar o sentido que o relato alcança e a sua função no contexto do regresso de Moisés ao Egito. Talvez, uma possível compreensão possa ser buscada na ligação desse episódio com a notícia da hostilidade de Maria e Aarão com Moisés por causa da sua esposa Cuchita (Nm 12,1-3). A ação de Séfora, a qual realiza um ato cultual, de certo modo a sublimou em relação aos irmãos de Moisés, pois com seu protagonismo livrou Moisés e o filho da morte.

Visto que Ex 4,24-26 trata da circuncisão, não se pode negar a sua ligação com a etiologia contida em Gn 17, com a ação de Josué antes de iniciar a conquista da terra prometida (Js 5,2-9) e com a trajetória do rito na história do antigo Israel, em particular no período pós-exílio (Ex 12,44; Lv 12,3; 19,23). ${ }^{9}$ A circuncisão tornou-se o elemento distintivo,

8 Cf. RIVIERA, 1963, p. 135-136; FRETHEIM, 1991, p. 79.

9 Gn 17,9-13 contém a ordem divina da circuncisão, que se torna sinal da aliança de Deus com Abraão e, por ele, com todos os seus descendentes. Abraão, Ismael e todos os varões, que nasceram em sua casa ou que lhe pertenciam, foram circuncidados no mesmo dia em que Deus dera essa ordem, em sinal de obediência. O relato sublinha que Ismael tinha treze anos quando foi circuncidado (Gn 17,25); já Isaac foi circuncidado, corretamente, ao oitavo dia (Gn 21,4). Estabelece-se, com isso, uma relação de diferença entre Ismael e Isaac e se fundamenta a prática no antigo Israel. No contexto da purificação da mulher após o parto (Lv 12,3), YHWH deu a Moisés a mesma ordem que dera a Abraão em Gn 17,12: a circuncisão de todo menino deve acontecer no oitavo dia. Fica uma dúvida: era lícito circuncidar no dia de sábado, caso fosse o oitavo dia? Jo 7,22-23 permite dizer que 
em função do compromisso com a aliança e das obrigações que dela decorrem. Uma abordagem, nessa linha, vai muito além da proposta deste artigo. Acenos serão feitos apenas para ajudar na compreensão do texto.

\subsection{Delimitação do texto}

O episódio seria algo em si totalmente estranho se não fosse a indicação de que ele ocorreu durante o percurso rumo ao Egito e que, de fato, Moisés tomou sua família para levá-la consigo. Isto não é sem sentido, pois atesta o estado de vida de Moisés: casado e com filhos, que vive na companhia de Jetro, seu sogro, razão para ligar o episódio às tradições madianitas (Ex 2,21-22; 3,1; 4,18; 18,1-27).${ }^{10} \mathrm{Um}$ fato, porém, é inegável: Ex 4,24-26 é um texto completo, com início, meio e fim..$^{11}$ Isto permite dizer que o texto, em si mesmo, possui o seu sentido. A introdução do fato pelo sinal macrossintático (wayhî) não deixa dúvidas de que se está diante de um novo episódio.

Com relação ao texto precedente (Ex 4,19-23), constatam-se duas mudanças, a primeira de local, passa-se da nova ordem recebida de YHWH, talvez ainda na tenda de Jetro, ${ }^{12}$ para o lugar do pernoite, a segunda de sujeito, pois o protagonismo passa de Moisés para Séfora. Admite-se, entretanto, que a presença de Séfora faz com que a experiência e a vida de Moisés em Madiã continuem presentes em sua nova etapa de vida: a missão. Este protagonismo não se repetirá na Bíblia

era praticada a circuncisão no dia de sábado. 0 que fazer se um filho nascesse durante a ausência do pai, por viagem ou morte?

${ }^{10}$ Parcas notícias sobre personagens decisivos para o antigo Israel podem não ser um impedimento para que a competência e sã imaginação encontrem espaço para preencher as lacunas da história. É o que faz, de forma brilhante e erudita, Marek Halter no seu romance sobre Séfora (2003).

${ }^{11}$ Há quem identifique em Ex 4,24-26 um episódio que interrompe a sequência narrativa (COATS, 1999, p. 45) e inclusive uma estrutura simétrica (RÖMER, 1994, p. 3), levando em conta o contexto próximo anterior e posterior: A: ordem de YHWH a Moisés $(4,19)$; B: execução (4,20); C: discurso proléptico de YHWH a Moisés; [4,24-26: ataque misterioso de YHWH contra Moisés]; A': Ordem de YHWH a Aarão (4,27a); B': execução (4,27b); C': discurso recapitulador de Moisés a Aarão.

${ }^{12}$ A experiência pessoal de Deus que Moisés teve no Horeb (Ex 3,1-4,18), na qual foi convencido por YHWH a regressar ao Egito, encontra a sua conclusão no breve diálogo que aconteceu com Jetro. A referência a Jetro $($ Ex 3,1; 4,18) funciona como moldura para 0 episódio e Ex 4,18 conclui o relato dessa experiência (KESSLER, 2013, p. 347). 
hebraica e não há como fundamentar se a experiência tenha resultado em benefício para Moisés, como pensam alguns. ${ }^{13}$ Fica evidente, porém, que a ação da mulher protagonista é que aparece de forma decisiva e determinante no evento relatado.

Além disso, dois movimentos são atribuíveis a YHWH: no primeiro, se aproxima para matar, mas, no segundo, se afasta devido ao rito que Séfora realizou e às palavras que proferiu, dando significado sacrifical ao gesto que livra da morte.

Com relação ao texto subsequente (Ex 4,27-31), não há continuidade temática no episódio, mas nota-se a mudança tanto de local (do lugar do pernoite para o monte de Deus), como de personagens, pois Séfora e os filhos saem completamente de cena, dando a impressão de que nada tenha acontecido ou querendo provocar ainda mais o ouvinte-leitor. Moisés, apesar de reaparecer, cede o protagonismo a Aarão, que recebe uma ordem de YHWH, cumprida por ele sem apresentar algum tipo de resistência.

\section{Tradução}

$\mathbf{4}^{24} \mathrm{E}$ aconteceu no caminho, no lugar do pernoite, YHWH $o$ alcançou e buscou matá-lo. ${ }^{25}$ Então, Séfora tomou uma pedra afiada e cortou o prepúcio do seu filho e tocou os pés dele, e disse: "porque tu és, para mim, esposo de sangues” ${ }^{26} \mathrm{E}$ afastou-se dele, porquanto [ela] disse: "esposo de sangues pelas circuncisões".

\section{Estrutura do texto}

Os três versículos, que compõem este brevíssimo episódio, se relacionam segundo uma estrutura concêntrica simples (A - B - A'). Esta permite uma rápida visualização dos movimentos realizados pelas personagens que atuam diretamente: YHWH e Séfora. A ação de YHWH abre (A) e fecha o episódio (A'). No centro (B), está a iniciativa

${ }^{13}$ Cf. FANULI, 1994, p. 47. 
de Séfora que, por meio de um ritual, no qual circuncida o filho, evita uma situação de morte. ${ }^{14}$

A: YHWH se aproxima com a intenção de matar (v. 24: voz do narrador)

B: Séfora realiza um ritual (v. 25: ação e voz de Séfora)

A’: YHWH se afasta desistindo da intenção de matar (v. 26: voz do narrador)

Não há diálogos, o narrador introduz a situação de forma temporal e espacial, pela qual conduz o ouvinte-leitor a perceber, depois de ser pego de surpresa diante de uma terrível descoberta ("YHWH o alcançou e buscou-o para matá-lo”), o astuto protagonismo de Séfora que soube, exatamente, o que devia fazer diante da situação para afastar o perigo. Neste sentido, Séfora é a única que tem, além da sua ação, uma fala direta que a faz crescer no conceito do ouvinte-leitor. $\mathrm{O}$ ritual, realizado por ela, aparece completo, pois há matéria (a circuncisão do prepúcio) e forma (o gesto com a fala de Séfora), pela qual é oferecido o seu significado. A informação final, em tom de conclusão, é também do narrador.

\section{Estrutura da narrativa}

A narrativa é coesa pela relação que pode ser estabelecida entre causa e efeito ou ação e reação. À ação de YHWH (causa) segue-se a reação de Séfora (efeito), que, por sua vez, torna-se uma nova causa (ação de Séfora), que produz um novo efeito (reação de YHWH). A possível situação de morte, cuja causa é YHWH, sem que haja qualquer explicação, é o fio condutor.

Quanto ao tempo, o episódio situa-se à noite, durante a viagem de regresso de Moisés e sua família para o Egito. O verbo, que abre o episódio (“e aconteceu”), introduz e assegura o aspecto temporal da narrativa.

${ }^{14}$ É possível ver estas três partes de outro modo: a) uma introdução, pela qual se expõe uma situação (v. 24a); b) uma narrativa que contém uma crise e a sua solução; c) uma conclusão que fundamenta uma etiologia (COATS, 1999, p. 44-45). 
Quanto ao lugar, há duas referências: "no caminho" e "no lugar do pernoite”, que figuram como uma etapa intermediária entre a saída de Madiã e a chegada ao Egito. Estas duas referências permitem ao ouvinte-leitor perceber que Moisés procurou realizar uma rota que fosse segura para si e para a sua família (o pernoite pode ter acontecido em um possível albergue ou em pontos estratégicos que os pastores estavam acostumados). Não se deve esquecer que Ex 3,1 afirma que Moisés levara o rebanho de Jetro, seu sogro, deserto adentro. Tal atitude não acontece sem um mínimo de prudência e conhecimento de rotas em busca de pastagens e de água fresca para o rebanho. 0 papel do pastor é, principalmente, garantir a sobrevivência do seu rebanho.

Quanto às personagens, que atuam neste episódio, elas podem ser classificadas de diretas e indiretas. O narrador, YHWH e Séfora são as personagens diretas. O protagonismo de Séfora aparece ao lado da investida de YHWH e a sua atuação equipara-se a de um mediador capaz de salvar Moisés e o seu filho da morte. Esse protagonismo de Séfora a coloca em linha de adequação com a ação das parteiras que salvaram os meninos da morte (Ex 1,15-31) e com a mãe, a irmã e a filha do Faraó que salva Moisés das águas (Ex 2,1-10). Note-se, ainda, que o filho circuncidado e Moisés são as personagens indiretas. Permanece, contudo, a dúvida quanto à vítima: Moisés ou o filho incircunciso? 0 texto não é claro, pois os sufixos pronominais podem ser atribuídos tanto a um como ao outro.

Quanto ao tema, a morte não é o ponto central, mas, sim, o modo como esta devia ser evitada. A possível vítima e as razões não são, por certo, determináveis. Estaria em jogo a ação de YHWH que exige o resgate do primogênito de Moisés, devido a ausência da circuncisão tanto dele quanto do seu filho? ${ }^{15}$ Sobressai, muito mais, a habilidade de Séfora que sabia, exatamente, o que deveria fazer para evitar a morte. Ela cumpriu o ritual da circuncisão que, segundo a tradição do antigo Israel, era uma atribuição do pai (Gn 21,4). Na falta do pai, era a mãe piedosa que fazia cumprir a lei, provavelmente, pelas mãos de

15 Cf. DOZEMAN, 2009, p. 155. 
um especialista. ${ }^{16}$ A ameaça que pode vir de YHWH, o protagonismo da mulher e a eficácia do ritual da circuncisão são os temas interligados que dão corpo e movimento ao episódio.

Os estágios da narrativa, introdução, ação, complicação, clímax e desfecho, podem ser percebidos claramente. "E aconteceu no caminho, no albergue, no lugar do pernoite" (introdução); "YHWH o alcançou" (ação); "e buscou matá-lo" (complicação); "Então, Séfora tomou uma pedra afiada e cortou o prepúcio do seu filho e tocou os pés dele, e disse: "porque tu és, para mim, esposo de sangues" (climax); "E afastou-se dele, porquanto [ela] disse: "esposo de sangues pelas circuncisões"” (desfecho).

\section{Comentário do texto}

$4{ }^{24} \mathrm{E}$ aconteceu no caminho, no lugar do pernoite, YHWH o alcançou

e buscou matá-lo.

A Peshita acrescenta “Moisés” após o verbo “aconteceu”, a fim de identificar a pessoa a qual se referem os sufixos pronominais de $3^{\text {a }}$ pessoa do masculino singular nos verbos "encontrar" e "matar". Com isso, afasta-se a dúvida, talvez desejada pelo texto, e se condiciona a interpretação.

A LXX considerada original, o Targum e o Targum do pseudo Jônatas, ao invés de "YHWH”, trazem "anjo de YHWH”. Manuscritos da LXX trazem somente “anjo” (Ex 3,2); a versão de Áquila traz “anjo de Deus”. O acréscimo mitiga o fato que, pelo contexto, cria muitas

${ }^{16}$ O fato da LXX e os Targumim serem tão próximos, permite pensar que a circuncisão, durante o período de perseguição helênica com Antioco IV Epífanes, tenha sido praticada por iniciativa corajosa das mães (RÖMER, 1994, p. 9-10). Por elas, a circuncisão continuou sendo realizada e sobreviveu em tempos difíceis de perseguição (1Mc 1,15.61; 2Mc 6,10). A postura de Isabel como protagonista no momento da circuncisão e da imposição do nome de João Batista insere-se nesse contexto. Visto que o seu marido não estava em condição de decidir, Isabel interveio para não permitir que as "lideranças locais" decidissem por eles (Lc 1,59-66). Sabe-se que na primeira metade do século II d.C., após a revolta judaica de Bar Kokba, que resultou na expulsão dos judeus de Jerusalém, a prática da circuncisão passou a ser punida pelo imperador Adriano com a pena de morte (HERBST, 2004, p. 171). 
Ano XXIIl • № $86 \cdot$ Jul/Dez 2015

dificuldades e escrúpulos, visto que a iniciativa de sentenciar o eleito ou seu filho com a morte fica atribuída a YHWH. Disto resultam as diferentes interpretações que atribuíram o feito ao "anjo da morte" ou ao "demônio noturno" 17 que foi enganado pelo sangue que saiu do prepúcio do filho. ${ }^{18} \mathrm{Com}$ isso, dissimulou-se a morte da possível vítima. ${ }^{19}$

O termo mālôn pode ser traduzido por "albergue", ${ }^{20}$ mas o sentido seria de um abrigo, isto é, de um local de refúgio no deserto (2Rs 19,23; Is 10,29; Jr 9,1), onde se pode descansar ou passar a noite, para no dia seguinte seguir a viagem. O termo tem esse sentido em Gn 42,27; 43,21. Estes dois textos ajudam a compreender Ex 4,24. Por eles, pode-se admitir que entre o Egito e Canaã os viajantes podiam realizar paradas ao longo da travessia pelo deserto do Neguev antes de alcançar o seu destino tanto numa como noutra direção.

O verbo pāgaš (alcançou, encontrou, topou com alguém ou um grupo), além deste versículo, só aparece mais uma vez, em todo o livro do Êxodo, em Ex 4,27. Nesta segunda ocorrência, Aarão é quem vem ao encontro de Moisés e o alcança no monte de Deus. O sentido desse verbo comporta o encontro com um inimigo e, portanto, existe a possibilidade de morte ou esta aparece como ocasião para afastá-la (Gn 32,18; 33,8; 1Sm 25,20; 2Sm 2,13; Os 13,8).

Surge, imediatamente, uma pergunta no ouvinte-leitor, caso, de fato, os sufixos pronominais se refiram a Moisés: ${ }^{21}$ por que YHWH

\footnotetext{
17 O Antigo Testamento possui diversas teologias. Se, por um lado, o bem e o mal podiam ser atribuídos, inicialmente, a YHWH (2Rs 6,33; Jó 2,10; Is 45,7), por outro lado, o desenvolvimento da religião do antigo Israel trouxe novas interpretações, passando a atribuir os males a forças angélicas réprobas (Jó 1,6-12; 2,1-7; Sb 2,23-24; Zc 3,2). Esta teologia foi plenamente assumida no Novo Testamento, em particular nos evangelhos, pois Jesus, o primogênito de Deus, se embate constantemente com Satanás e seus anjos.

${ }_{18}$ Cf. RIVIERA, 1963, p. 134-135; SCHARBERT, 2001, p. 37.

${ }^{19}$ Isso aparece no Targum fragmentado de origem palestinense: "Quando o Destruidor se afastou dele, Séfora deu graças e disse: 'Quanto amado é o sangue da circuncisão, o qual salvou meu esposo das mãos do Anjo da morte’”. A tradição judaica e cristã buscou interpretar o texto a partir do episódio da noite de páscoa, em que YHWH passou eliminando os primogênitos do Egito (Ex 12,12-14.29), de modo que Ex 4,24-26 passaria a funcionar como um prólogo pascal (RÖMER, 1994, p. 6).

${ }^{20}$ Cf. ALONSO SCHÖKEL, 1997, p. 378.

${ }^{21}$ A lógica narrativa permite que os sufixos se refiram a Moisés (RÖMER, 1994, p. 7), sem exclusão de outras possibilidades, causadoras das mais diferentes interpretações, gerando inclusive estatísticas (LUCIANI, 2012, p. 161-165).
} 
mataria o que elegeu para uma missão libertadora? Não faz nenhum sentido, visto que o próprio YHWH já havia informado Moisés que estavam mortos os que desejavam matá-lo (Ex 2,23; 4,19). Outras questões surgem: Por que o caminho de retorno ao Egito se torna uma possibilidade de morte? Que razões teria tido YHWH para agir dessa maneira contra o seu eleito? Fato é que se YHWH veio ao encontro para matá-lo, não o fez. Este último elemento atenua, até certo ponto, diante do ouvinte-leitor, o impacto da violência que recai sobre uma vítima que é inocente. ${ }^{22}$

As vicissitudes da vida não transcorrem sem a ciência e o assentimento dos planos de Deus, que, por sua vez, envolvem igualmente os planos do ser humano. Por isso, tais planos não estão desvinculados da história e do seu curso que segue a lógica da relação entre causa e efeito. Na história, porém, existe sempre o espaço para que aconteça tanto o previsível como o imprevisível divino aos olhos do ser humano.

A experiência que Moisés fez de Deus no monte Horeb (Ex 3,1-6) não foi, por certo, prevista por ele, mas aconteceu no tempo oportuno para que, nele, se reacendesse o seu ímpeto libertador. Se, por um lado, a proximidade que experimentou de Deus não lhe causou risco de morte, nem mesmo quando tentava dissuadir Deus de seus planos; por outro lado, o eleito de Deus, chamado para uma missão libertadora, no caminho de regresso ao Egito e executando a ordem recebida, volta a experimentar o risco de morte. É possível admitir, também, uma ligação entre a ordem de YHWH: "Não te aproximes até aqui; tira as tuas sandálias de teus pés, pois o lugar que tu estás de pé, sobre ele, é solo santo.” (Ex 3,5) e o gesto que Séfora realizou: "tomou uma pedra afiada e cortou o prepúcio do seu filho e tocou os pés dele, e disse: "porque tu és, para mim, esposo de sangues.” (Ex 4,25). Os dois episódios confirmam que YHWH, ao agir, deixa espaço

${ }^{22}$ Cf. FRETHEIM, 1991, p. 76. O mesmo não pode ser dito sobre Davi que, por causa do seu pecado de adultério com Betsabeia, não foi atendido por YHWH que sentenciou de morte a criança, fruto dessa relação (2Sm 12,14-24). Davi, porém, continuou sendo o eleito de YHWH e da nova relação nasceu Salomão que assumiu o trono no seu lugar. A diferença que existe entre os episódios reside na explicação dada para a ação de YHWH. No caso de Davi, sabe-se que foi por seu pecado, mas no caso de Moisés só é possível conjecturas plausíveis. 
Ano XXIIl • № $86 \cdot$ Jul/Dez 2015

para que a mediação cumpra o seu papel no tempo e na ocasião da sua manifestação. ${ }^{23}$

O Deus que Moisés encontrou pessoalmente no monte Horeb (Ex $3,6)$ é idêntico ao Deus dos patriarcas, ${ }^{24}$ mas, pelo seu modo de agir, revela que não está preso a um lugar. É um Deus que possui mobilidade e é capaz de alcançá-lo no caminho. Assim, a experiência da morte, como possibilidade dela acontecer ao longo do caminho, como ação de Deus, não alterou a decisão que Moisés tomou de regressar ao Egito, isto é, não fez com que ele recuasse ou mudasse a sua decisão. Fica certo, então, que a morte nunca se afastará da vida e da missão que Moisés assumiu. Ela se manifestará mais de uma vez diante do Faraó e, principalmente, ao longo dos anos transcorridos no deserto, para, enfim, acontecer diante da terra prometida (cf. Dt 34).

Nada impede de pensar que o filho tenha dado sinais de enfraquecimento pelo caminho ou que alguma doença tenha se manifestado, fazendo com que este mal fosse afastado pelo gesto cultual e salvífico da circuncisão. ${ }^{25}$

$4{ }^{25}$ Então, Séfora tomou uma pedra afiada e cortou o prepúcio do seu filho e tocou os pés dele, e disse: "porque tu és, para mim, esposo de sangues".

Ao invés de: "porque tu és, para mim, esposo de sangues”, a LXX apresenta um texto bem diferente: "e caiu [Séfora] sobre [seu] pé e disse: o sangue da circuncisão do meu menino estancou”. O gesto de Séfora teria sido dirigido ao "anjo de YHWH" em razão de Moisés ou de seu filho como permite o Texto Massorético. A Vulgata, porém, dá suporte para o Texto Massorético. A mesma mudança na LXX ocorre na fala do narrador no v. 26 do Texto Massorético ("esposo de sangues pelas circuncisões”). Com essa mudança, a LXX possui outra interpretação para o fato, colocando a atenção sobre a circuncisão realizada por

${ }^{23}$ Cf. FRETHEIM, 2004, p. 78-79.

${ }^{24}$ Cf. KESSLER, 2013, p. 351.

${ }^{25}$ O valor salvífico atribuído à circuncisão aparece, claramente, nos targumim (Bible Works 9.0): "Se não fosse pelo sangue desta circuncisão, meu marido teria merecido a morte" (Targum Onquelos); "Possa o sangue desta circuncisão expiar a culpa do meu marido" (fragmento de um Targum); "Que bênção é este sangue da circuncisão” (Targum Neofiti 1). 
Séfora, apresentada como um ato quase sacrifical que conseguiu a libertação de Moisés do misterioso perigo de morte.

Diante do risco de morte, Séfora surgiu como alguém que não somente tomou a iniciativa, mas se demonstrou capaz de intervir e bloquear a ação de YHWH. Coube a ela o protagonismo salvífico. $\mathrm{O}$ ouvinte-leitor já havia encontrado a mediação salvífica das parteiras (cf. Ex 1,15-21), da mãe, da irmã e da filha do Faraó a favor de Moisés (cf. Ex 2,1-10). Com isso, Moisés acumula, na sua história, a intervenção de várias mulheres, das quais duas delas não são filhas de Israel. Dentre todas essas mulheres, que atuam a favor de Moisés, somente Séfora é citada por nome, ${ }^{26}$ o que a torna ainda mais importante e central no relato. Enquanto as outras mulheres salvaram Moisés do Faraó, Séfora salvou-o das mãos de YHWH. ${ }^{27}$ Desta feita, o papel libertador de Séfora antecipa o papel libertador de Moisés em relação ao seu povo. ${ }^{28}$

O termo șōr, em todo o livro do Êxodo, só ocorre neste texto e significa um artefato de pedra que servia para cortar com precisão. A indicação do uso de uma pedra afiada confere antiguidade ao costume. ${ }^{29}$ Esta pedra afiada era o instrumento adequado para se proceder

\footnotetext{
26 "Se por um lado a Bíblia não se interessa em conservar o nome do faraó e de seus nobres, por outro, recorda muito bem o das parteiras, e lhes confere nomes com profunda simbologia. Séfora significa beleza e Fua, esplendor" (SILVA, 2004, p. 36). Pode ter sido proposital criar uma relação entre no nome da primeira parteira, Sefra e da esposa de Moisés, Zipora ("pardal”?). Os nomes variam de acordo com as versões. "Sefra e Fua são apresentadas como mulheres com coragem civil, desobedientes em relação à ordem injusta, opondo-se à maior autoridade, astutas, capazes de enganar o poder ingênuo. Chama, pois, a atenção do leitor o fato de elas mentirem ao faraó, afirmando que as hebréias seriam mais vivas do que as mulheres egípcias e que, por essa razão, nem precisariam da ajuda da parteira no momento de darem à luz (v. 19)... Portanto, parece ser até um elemento humorístico na narrativa, quando esta última dá a entender que o faraó, como homem, não entende nada de mulher e de trabalho de parto" (GRENZER, 2004, p. 22-23; sobre a princesa do Egito, a irmã e a mãe de Moisés, p. 24-32).

${ }_{27} \mathrm{O}$ fato de Séfora circuncidar o menino permite pensar que Moisés foi, de fato, o alvo do misterioso ataque (CHILDS, 2003, p. 132).

${ }^{28}$ Cf. FRETHEIM, 1991, p. 80.

${ }^{29}$ Por que usar uma pedra afiada ao invés de um artefato feito de metal? Pode-se pensar que, por um lado, se desejou respeitar a antiguidade, pois ainda não existiam facas de metal ou porque o artefato de pedra produzia um corte mais preciso e limpo que o de metal, facilitando a cicatrização (NOTH, 1977, p. 62; SICRE, 2002, p. 158).
} 
Ano XXIII • № $86 \cdot$ Jul/Dez 2015

com a circuncisão no Antigo Oriente Próximo. ${ }^{30}$ Se a vocalização for mudada para șar, o mesmo termo passa a significar adversário ou inimigo (cf. Gn 14,20; Nm 10,9; 24,8). A mesma raiz, de forma defectiva, șōr e șôr indica Tiro (cf. Js 19,29; 2Sm 5,11; 24,7), região costeira do Mediterrâneo habitada por fenícios, cujo porto era importante (cf. Mt 11,21; At 21,3).

A ação de Séfora se equipara à ação da investida de YHWH e interpreta que a situação de morte deveu-se a não circuncisão do filho. Com esse gesto, comumente atribuído ao pai e na ausência dele à mãe que representa a família, Séfora, assumindo um protagonismo cultual e vicário (porque salvífico), indicou que o menino pertencia ao Deus de Moisés. Séfora, pela lógica da narrativa, cumpriu a ordem dada a Abraão (cf. Gn 17,12), não na ausência do pai, mas na sua presença, à diferença de $1 \mathrm{Mc} 1,61$.

A dificuldade de atribuição dos sufixos pronominais aos sujeitos permanece, o que permite aplicar o gesto cultual de Séfora tanto ao filho como a Moisés. ${ }^{31}$ A ação seguinte, porém, permite fazer uma distinção de sujeitos e, de certa forma, dissipar a dificuldade: aplicou aos pés dele, é um eufemismo que significa que Séfora tocou com o prepúcio do filho o órgão genital de Moisés (RAVASI, 2007, p. 41). ${ }^{32}$ Este gesto de Séfora fez da esposa de Moisés uma mulher com direitos junto ao antigo Israel não só pelo matrimônio, mas pelo rito do sangue, gerando, inclusive, uma garantia para os seus filhos junto aos filhos de Israel.

\footnotetext{
${ }^{30}$ Cf. DOZEMAN, 2009, p. 155.

${ }^{31}$ É possível aceitar a não circuncisão de Moisés, mas isso resultaria estranho, pois se a filha do Faraó não o tivesse circuncidado, a própria mãe que o amamentou por três anos poderia ter feito. Não obstante isso, deixar a circuncisão para a filha do Faraó seria ainda mais condizente, pois cumprindo esse gesto, usado e praticado no antigo Egito, teria dado a ela o status de mãe do menino. Segundo uma antiga tradição rabínica palestinense, Moisés nasceu bom, isto é, nasceu circunciso. Como ele: Noé, Sem, Melquisedec, Jacó, etc. A razão deve-se ao fato de não se encontrar a notícia da circuncisão dessas personagens. $321 \mathrm{Sm} 24,4$; Rt 3,4.7; Is 6,2 são outros exemplos de eufemismos que indicam o órgão genital masculino. Para os que interpretam o fato como uma falta cometida por Moisés, o eufemismo significa que Séfora teria, também, "circuncidado" a Moisés (GARCÍA LÓPEZ, 2007, p. 50).
} 
Pelo rito da circuncisão do filho unido ao sentido matrimonial,,$^{33}$ Séfora fica definitivamente ligada a Moisés e seus filhos passam a fazer parte do seu povo. É o direito estrangeiro adquirido não por força de lei, mas pelos laços íntimos que ratificam o que Deus uniu o homem não pode separar. O afastamento de YHWH, que desiste de infligir a morte, confirma a força do gesto realizado por Séfora. ${ }^{34}$ Isto, porém, não foi visto e aceito como solução para a questão da pureza legal. Nm 12,1-16 alude a um episódio que exemplifica o fato: o casamento de Moisés com uma mulher estrangeira gerou conflitos com os irmãos de Moisés. ${ }^{35}$ YHWH veio em defesa de Moisés e, em última instância, em defesa da mulher estrangeira de Moisés e contra os irmãos, em particular contra Miriam que foi castigada com a lepra e teve que experimentar o que significa ser segregada da comunidade dos libertos. É próprio da mãe se precipitar para proteger a sua progênie e, por ela, o pai para quem gerou os filhos. O filho circuncidado, provavelmente, foi Gersam, ${ }^{36}$ nome que Moisés deu ao seu primogênito para significar a sua condição em Madiã: um "estrangeiro residente" em uma terra que não é a sua (cf. Ex 2,22; 18,3). Sabe-se que, além de Gersam, Moisés teve outro filho, chamado Eliezer (cf. 1Cro 23,15),

\footnotetext{
${ }^{33}$ Há quem defenda que Ex 4,24-26 seja indicador de uma passagem do rito de preparação do matrimônio (pré-nupcial) para o rito da circuncisão infantil (PROPP, 1993, pp. 495-518; AUZOU, 2008, p. 133). Há quem discorde e, com base na expressão, "esposo de sangues das circuncisões” (Ex 4,26), tenha formulado a hipótese de que, no início, essa expressão era uma interpretação pejorativa sobre a ação exagerada usada por Davi para ter o seu matrimônio com Micol (1Sm 18,20-27), contra os seus adversários (FROLOV, 1996, p. 523). ${ }^{34}$ A declaração de Séfora, "porque és para mim esposo de sangues" possui a mesma força e intensidade da declaração de Rute a Noemi (Rt 1,16-18). Razão pela qual o vínculo livremente estabelecido não pode mais ser desfeito. O vínculo de Séfora com Moisés e de Rute com Noemi é duradouro e só a morte pode separar (FERNANDES, 2012, p. 36-37).

${ }^{35}$ É possível que a alusão à mulher de Moisés, como sendo uma cuchita, seja o testemunho de que se está diante de tradições diferentes sobre o fato.

${ }^{36}$ O Targum do Pseudo Jonatas faz clara identificação: "24E veio a acontecer no caminho, no lugar do albergue, que o Anjo do Senhor o encontrou e quis matá-lo [Moisés], porque seu filho Gersam não tinha sido circuncidado por Jetro, seu sogro, quem não lhe permitiu a circuncisão. Eliezer, porém, tinha sido circuncidado por força de um acordo que eles tinham feito. 25E Séfora tomou um cutelo e cortou o prepúcio de Gersam, seu filho, e levou o que tinha cortado aos pés do Anjo Destruidor e disse: "Meu esposo quis circuncidá-lo, porém seu sogro não o permitiu. Possa então o sangue desta circuncisão expiar a culpa de meu esposo'. 26E o Anjo Destruidor desistiu dele. Então, Séfora deu graças e disse: 'Quão amado é o sangue da circuncisão, o qual salvou meu esposo das mãos do Anjo Destruidor." (Targum Pseudo Jonatas in Bible Works 9.0).
} 
Ano XXIIl • № $86 \cdot$ Jul/Dez 2015

nome que significa "Meu Deus é auxílio", em honra ao Deus de seu pai (cf. Ex 18,4). ${ }^{37}$ Ex 4,20 entra em conflito com este versículo, pois menciona a prole de Moisés e de Séfora no plural e não no singular.

A revelação de YHWH a Moisés, como "Deus de seu pai, o Deus de Abraão, o Deus de Isaac e o Deus de Jacó” (Ex 3,6), está no nível da afirmação de que YHWH é o Deus que deu a Abraão a circuncisão como sinal de aliança e de pertença ao povo que dele deriva (cf. Gn 17). Ser circuncidado significa tornar-se membro desse povo. É algo de todo estranho, pois não existe algum indício textual pelo qual se possa dizer que Moisés teria sido circuncidado ou que tivesse circuncidado os seus filhos.

É possível admitir que a circuncisão fosse praticada pelos madianitas, visto que Séfora agiu com precisão, pois sabia o que deveria fazer. ${ }^{38}$ Além disso, não existe algum texto em que os madianitas são denominados de incircuncisos, como ocorre com outros povos com os quais o antigo Israel entrou em contato (Gn 34,13-24; 1Sm 18,2527; Jz 15,18). Surgem questões: se os filhos de Israel não deixaram de praticar a circuncisão enquanto estiveram no Egito (Js 4,2-5a), por que Moisés não teria sido circuncidado ou por que teria deixado de circuncidar seu filho? A circuncisão dos filhos de Moisés não deveria ter acontecido ainda em Madiã? Ao lado destas questões, outra se impõe: por que, segundo Js 5,5b, Moisés não impôs a circuncisão aos filhos de Israel que nasceram durante o período do deserto? Diante

\footnotetext{
${ }^{37}$ Não há como dizer se Eliezer nasceu em Madiã, no caminho de regresso para o Egito ou no próprio Egito. "Pode-se pensar que Eliezer nasceu antes da revelação do Senhor e do seu Nome a Moisés no monte Horeb. Isso justificaria o nome teofórico elaborado com o epíteto El e não com o Tetragrama Sagrado, YHWH” (FERNANDES - GRENZER, 2011, p. 131). As notícias sobre os filhos de Moisés são parcas, pois não lhe foram atribuídas responsabilidades junto aos libertos que adentram na terra prometida após a morte de Moisés. Tampouco se sabe a respeito da morte deles. A ausência de protagonismo, no caso de Eliezer, equipara-se ao do servo de Abraão, que não se tornou seu herdeiro (Gn 15,2). ${ }^{38}$ Segundo uma interpretação rabínica, a importância da circuncisão para os madianitas remontaria à tradição que vinda do próprio Abraão através de seus filhos com Cetura, dentre os quais está Madiã (Gn 25,1-4). Por isso, Séfora sabia o que deveria fazer. Moisés, ao contrário, teria que receber a lei da circuncisão para transmiti-la aos filhos de Israel (DERBY, 1990, p. 226). Isso, porém, não explica o fato e cria outra dúvida: por que uma geração inteira teve que ser circuncidada novamente ao lado da que não fora circuncidada antes de tomar posse da terra prometida? (Js 5,2-3.4-8).
} 
desses impasses, o gesto de Séfora, no contexto da tradição bíblica, não foi somente um ato cultual, mas um ato de justiça.

Este gesto deu a Moisés e Gersam uma nova condição, pois pela circuncisão puderam regressar ao seu povo, no Egito, não mais como estrangeiros, mas como membros do povo da aliança. A circuncisão, acontecendo pelo caminho, passou a exigir que o ritual, em hipótese alguma, deixasse de ser realizado. Com isso, o sinal de pertença aos descendentes de Abraão passou a marcar uma nova fase na vida do antigo Israel, pois sem a circuncisão não poderia ter celebrado a páscoa na terra prometida (Ex 12,48; Js 5,2-10). ${ }^{39}$

A explicação do gesto, não do que ele significa no contexto, ${ }^{40}$ contido no eufemismo ("porque tu és, para mim, esposo de sangues"), denota, por um lado, que pela circuncisão o menino passou a pertencer não mais a Moisés, seu legítimo pai, mas a Deus que propicia a fecundidade dos genitores; por outro lado, as três ações (tomou cortou - tocou) ficam interligadas, pois o filho circuncidado foi o fruto obtido da união de Moisés com Séfora e o matrimônio fica ratificado pelo gesto que ela realizou. ${ }^{41}$ A explicação dada por Séfora soa como uma fórmula ou declaração feita por ocasião do matrimônio ou da celebração ritual da circuncisão (SCHARBERT, 2001, p. 37). ${ }^{42}$

A locução esposo de sangues, em toda a Bíblia hebraica, ocorre apenas nos vv. 25-26. É importante notar que hōtēn (sogro) e hātan (noivo, esposo, genro) provenham da mesma raiz. Nas alusões a Jetro, como sogro de Moisés, utilizou-se hōtēn (Ex 3,1; 18,1.2.5.12.14). A ligação idiomática entre esposo (hātan) e circuncisão (hātana) ainda existe no árabe (SICRE, 2002, p. 159). Não há como não ver, então, a forte ligação matrimonial que se estabelece entre os gestos de Séfora e o termo usado. Ao lado disso, a locução pelas circuncisões é também

\footnotetext{
${ }^{39}$ Esta celebração aconteceu em Guilgal, porque em uma colina se enterravam os prepúcios dos jovens que passavam por um ritual de iniciação à maturidade (SICRE, 2002, p. 159) e marcou o fim do dom do maná (Js 5,11-12), que, por sua vez, marcava o fim do tempo errante pelo deserto. 0 valor da circuncisão aparece acentuado na tradição targúmica que a associa ao sangue da páscoa (Ex 12,21-28).

${ }^{40}$ Cf. CHILDS, 2003, p. 126.

${ }^{41}$ Cf. FERNANDES - GRENZER, 2011, p. 117-119.

${ }^{42}$ A conexão entre circuncisão e matrimônio já era admitida por muitos (NOTH, 1977, p. $62)$.
} 
Ano XXIIl • № $86 \cdot$ Jul/Dez 2015

única em toda a Bíblia hebraica. Entretanto, Moisés não é simplesmente hātan para Séfora, mas ba'al, isto é, dono de sua mulher.

A tendência comum de se pensar Gersam e Eliezer como crianças está na origem das dificuldades na hora de se atribuir a quem Séfora tocou. Em momento algum é dito que os filhos de Moisés ainda eram crianças. Admitindo-se que os filhos de Moisés estavam em idade matrimonial, o gesto realizado por Séfora adquire maior significado. Um dado é certo: Séfora, com sua reação imediata diante do perigo de morte, conseguiu, pelo rito da circuncisão, a salvação de Moisés. Este gesto, realizado pela mulher do futuro libertador dos filhos de Israel, adquiriu força histórica e litúrgica, em particular para os tempos e circunstâncias difíceis.

$4{ }^{26} \mathrm{E}$ afastou-se dele, porquanto ela disse: "esposo de sangues pelas circuncisões".

O Pentateuco Samaritano, mudando a pessoa do sufixo pronominal para o feminino, "dela”, ao invés de “dele”, interpreta que YHWH teria se afastado de Séfora e não de Moisés ou do filho circuncidado.

Não fica claro, pela narrativa, quem foi que se afastou, se foi Séfora quem se afastou de Moisés ou se foi YHWH quem retrocedeu no seu propósito. Esta última é a mais seguida na história da interpretação. ${ }^{43}$ O gesto de cortar o prepúcio e tocar com ele a genitália de Moisés, ou a sua declaração: porque tu és, para mim, esposo de sangues; ou, ainda, a explicação do narrador que agregou à declaração o gesto por ela realizado: esposo de sangues pelas circuncisões, não dirime toda a questão. 0 fato de o termo circuncisão estar no plural abre uma margem para se pensar que Séfora também circuncidou Moisés ou o gesto também lhe foi propício. Uma razão suficiente para se usar, neste contexto, sangue no plural. O texto não permite tirar conclusões sobre

\footnotetext{
43 "Por ora, a estranha aventura daquela noite revela a Moisés alguma coisa totalmente impensada: Javé lhe rouba a mulher que - segundo uma interpretação - 'o deixou' (Ex 4,26). Iremos reencontrá-la depois, com seu pai, para o qual voltara com os filhos (cf. 18,2-6). Moisés, pois, acaba sozinho, no seu face a face chocante com Deus” (STANCARI, 1987, p. 36).
} 
essa dupla circuncisão. Só mais duas vezes se usou o plural "sangues" no livro do Êxodo, no contexto da vingança (cf. Ex 22,1-2).

Claro está, porém, que YHWH da mesma forma que se aproximou para matar, afastou-se sem dizer uma palavra. Em ambos os casos, a ação de YHWH é decisiva e eficaz. A circuncisão não é um ritual mágico, mas um ato satisfatório e expiatório. ${ }^{44} \mathrm{O}$ gesto e as palavras de Séfora, por um lado, alcançaram êxito, mas, por outro lado, revelou-se que YHWH é livre em suas ações e em suas decisões. Por certo, evidencia-se que as ações e palavras humanas contam para evitar que YHWH leve a termo uma decisão. Isto seria compreendido sem grandes problemas segundo a ótica da justa retribuição com base na obediência à lei.

Séfora conseguiu mostrar como uma ação humana tem valor diante de YHWH e, por sua ação sacerdotal, adquiriu uma via de relação com o Deus de seu esposo, que pela circuncisão passa a ser, também, o Deus de seu filho. ${ }^{45}$ A ação de Séfora abre um precedente na história de Moisés que é salvo pela circuncisão de seu filho, mas também pode inaugurar a compreensão da circuncisão como o resgate do primogênito sobre o qual YHWH possuía o direito de vida ou de morte.

O protagonismo de Séfora pode advogar a favor da formação de Moisés que regressa ao seu povo com a experiência religiosa que fez junto aos madianitas. Séfora fez justiça à família que pertencia, pois Jetro seu pai era sacerdote de Madiã. Não há, porém, como provar que Ex 4,24-26 seja uma etiologia sobre a prática da circuncisão que passa da experiência religiosa dos madianitas para os filhos de Israel através de Séfora, esposa de Moisés. É possível aceitar que, pelo contexto, Séfora era quem sabia como executar com êxito um ritual de proteção contra o ataque noturno da divindade. ${ }^{46}$

Percebe-se, não obstante o forte protagonismo de Séfora, que a sua ação quase fica na penumbra diante da força da circuncisão. Sobressai, assim, muito mais, nos comentários pré-críticos, o ritual

${ }^{44}$ Cf. NEPI, 2002, p. 130.

${ }^{45}$ Cf. FRETHEIM, 1991, p. 79.

${ }^{46}$ Cf. DOZEMAN, 2009, p. 155-156. 
Ano XXIII • № $86 \cdot$ Jul/Dez 2015

realizado do que a iniciativa da esposa de Moisés que é uma mãe pronta a intervir quando está em jogo o destino da família. ${ }^{47}$

Em vários momentos da missão, Moisés teve que conviver com o "aquecimento" e o "esfriamento" da ira de YHWH em relação ao seu povo. Este afastamento de YHWH, que equivale a desistir de um propósito de morte, pode ser considerado como sendo o primeiro gesto de misericórdia que Moisés experimentou de seu Deus e que, por ele, muito será explorado para livrar o povo da obstinação do Faraó (cf. Ex 5,22-6,1), do extermínio por causa dos murmúrios (cf. Ex 14,10-14; 15,22-16,36) e da desobediência (cf. Ex 32,11-14.30-35; 33,12-17.18-23; $34,5 b-9)$.

\section{Considerações finais}

Este episódio tratou, por um lado, sobre o risco de morte que circundou Moisés durante uma parada no caminho rumo ao Egito, mas, por outro lado, do protagonismo de Séfora que afastou tal risco. $O$ ouvinte-leitor fica perplexo ao perceber que o próprio YHWH foi quem envolveu o eleito e sua família neste contexto de morte. Entretanto, se o episódio for visto como elemento antecipador, uma prolepse, o que nele aconteceu não só é atenuado, mas passa a ser visto como necessário para a compreensão do que YHWH realizou, na noite pascal, para tirar o seu povo das mãos do Faraó.

O que adveio no caminho de regresso ao Egito prefigurou o que YHWH fez para livrar o seu povo ao preço do sangue dos primogênitos do Egito. Não há como mudar a história da salvação, apenas deixar-se interpelar por ela e perceber que YHWH agiu depois de ter dado ao Faraó todas as chances para vencer a sua obstinação, como deu a Moisés a graça de estar ao lado de Séfora, que o livrou da morte. Assim, o episódio permite que se julguem os motivos que levaram o povo a pensar que YHWH, por meio de Moisés, teve a intenção de fazê-lo morrer. Ex 14,11; 16,2; 17,3 são textos que lembram tal julgamento por parte do povo, quando teve diante de si uma situação próxima

${ }^{47}$ Cf. CHILDS, 2003, p. 130. 
de morte. O perigo que o regresso ao Egito representou, criou, igualmente, uma base para a sua proibição e para que o povo liberto não alimentasse o desejo de voltar (Ex 13,17; Dt 17,16).

A circuncisão era, inicialmente, um rito de passagem da puberdade para a maturidade pela capacidade de gerar descendência, mas se tornou, no antigo Israel, o sinal da aliança, pela qual Deus concedia a sua bênção aos descendentes de Abraão. A circuncisão, como sinal na carne, não é, por certo, garantia de salvação. Esta exige a participação do ser humano, como fez Séfora, mostrando que há sacrifícios a serem feitos quando a vida é o que está em jogo. 0 rito pode ser importante e fundamental, mas não teria tido a eficácia desejada sem a participação de Séfora, mulher proativa que se colocou entre a vida e a morte de seu marido. ${ }^{48}$ Assim, o referencial sacerdotal de Moisés não é mais Jetro, mas Séfora que, por seu gesto sacrifical, deu-lhe uma nova oportunidade, não só de vida, mas de possibilidade para cumprir a sua missão. O futuro Israel, liberto do Egito, não terá somente Moisés como referencial, mas guardará a lembrança do papel que Séfora desempenhou.

Na circuncisão do filho de Moisés, pelas mãos de Séfora, antecipou-se a ação de YHWH a favor do seu povo. O sangue derramado do prepúcio cortado do filho de Moisés aponta para o sangue dos animais sacrificados na noite libertadora (cf. Ex 12,1-14.21-28), mas também aumenta o significado da missão de Moisés, pois o sangue não se afastou dele e das suas ações. Suas mãos estiveram e continuaram "manchadas" de sangue. Assim como o sangue do filho circuncidado salvou Moisés da morte, o sangue dos animais imolados, de igual modo, serviu para afastar o anjo exterminador dos primogênitos dos

\footnotetext{
${ }^{48} \mathrm{O}$ reconhecimento do importante papel de Séfora não é uma novidade nos meios acadêmicos, dentro e fora do cristianismo (JACOBS, 2008, p. 314-315). Séfora, porém, representa o que de mais normal existe e se espera no protagonismo de uma típica mulher no contexto do Antigo Oriente Próximo. A Bíblia hebraica está repleta de exemplos: Sara, Agar, Débora, Noemi, Rute, Judite, Ester, a mãe e os sete filhos mártires, etc. O que era normal no passado tornou-se motivo de exaltação no presente, pois é preciso resgatar o protagonismo do feminino na sociedade ocidental que o depauperou e, em muitos casos, passou a prescindir dele, deixando ao homem o total controle da situação.
} 
Ano XXIIl • № $86 \cdot$ Jul/Dez 2015

filhos de Israel, dando início ao novo sentido da páscoa do cordeiro, o primogênito a ser imolado, em relação ao êxodo do Egito. ${ }^{49}$

Séfora desponta como mediadora salvífica como Moisés, ou até em um nível maior, pois ela realizou um ato salvífico que libertou da morte o futuro agente libertador dos filhos de Israel, isto é, do primogênito de YHWH. Moisés é um libertador que não subsistiria sem a mediação libertadora das mulheres que YHWH colocou em sua vida. Como Jacó, depois de lutar com Deus toda a noite se tornou Israel, Moisés, depois de ver a morte de perto, como provação que vem de Deus, tomou conhecimento da força divina que o impulsionou a regressar ao Egito.

Séfora torna-se um antítipo de outras mulheres, por exemplo, a mulher de Jó que desejou a morte de seu esposo chagado (Jó 2,9-11) ou um modelo que pode ter inspirado outras mulheres, como é o caso de Débora, que ao lado de Gedeão, salvou os filhos de Israel das mãos dos cananeus $(\mathrm{Jz} 4,9)$. Dessa forma, o antigo Israel deve aprender a ler e a compreender a Torá, que termina com a morte de Moisés diante da terra prometida (Dt 34,5-8). Esta terra se tornou a mãe de todas as futuras gerações dos novos circuncisos que pertencem a YHWH.

Séfora, também, é a mulher que não temeu enfrentar YHWH com o conhecimento que tinha e a "arma" da qual dispunha para evitar a possibilidade da morte acontecer. Séfora foi para Moisés o que as parteiras foram para os primogênitos dos filhos de Israel. Ela é a mulher cheia de mérito, como uma "nova Eva”, mulher universal, que age para que seu marido, como um "novo Adão”, homem universal, siga a missão que Deus lhe atribuiu.

O que se passou "no lugar do pernoite", por um lado, habilitou Moisés na sua missão como servo de YHWH que atendeu à iniciativa da mulher madianita; mas, por outro lado, ajudou-o a não esquecer

\footnotetext{
${ }^{49}$ GARCÍA LÓPEZ, 2007, p. 50. Compreende-se “que toda la estructura de la teología paulina en relación al bautismo está estrictamente relacionada con la doctrina judía contemporánea de la circuncisión... Así como los contemporáneos judíos de Pablo ingresaban al Pacto por medio de la circuncisión, de la misma manera los cristianos, a través del bautismo, ingresaban dentro del Nuevo Pacto consumado con la muerte y resurrección de Cristo" (HERBST, 2004, p. 172).
} 
a experiência da derrota, quando procurou fazer justiça com as suas próprias mãos e acabou tendo que fugir do Egito (Ex 2,11-15). ${ }^{50}$

Moisés, que se tornará na narrativa bíblica o grande agente libertador ao lado de YHWH e o mediador da Torá, se viu impotente diante do “perigo de morte”. No fundo, é a Torá que se viu impotente nas mãos dos que, em nome de YHWH, quiseram imprimir um rigor desumano e causar a morte do inocente. Esta é a pior tentação que pode se tornar fato: usar o nome de Deus e sua lei não para salvar, mas para condenar à morte. Por detrás da ação inimiga de YHWH se escondia a ação dos que queriam defender a pureza legal injusta e se tornaram como Faraó. Não é difícil que o perseguido se torne perseguidor e passe a fazer a mesma coisa. A história do antigo Israel e da Igreja estão repletos de exemplos que ainda se repetem no contexto sócio-pastoral e, pior ainda, com fundamentação "bíblico-teológica”.

Difícil não reconhecer o papel subversivo de algumas mulheres como Séfora, principalmente se são estrangeiras, diante da crise que se instaurou em Judá-Jerusalém, pelo rigor da ortodoxia judaica oriunda da golah babilônica com Esdras-Neemias (NEPI, 2002, p. 134-135), que ordenaram o divórcio para os casamentos mistos (Esd 9,1-10,44; $\mathrm{Ne}$ 13,23-31; Nm 12,1). Esse rigorismo aflorou na sociedade do antigo Israel pós-exílico como a mesma intensidade das pragas do Egito. ${ }^{51}$

A vocação e a missão de tantos homens e mulheres em muito se assemelham ao que se passou com Moisés. Quando se aceita seguir os planos de Deus, aceita-se também a possibilidade de se experimentar várias provações. Com isso, não se conhece somente a força da presença de Deus, mas, igualmente, o que ela representa: a falta de qualquer segurança humana, pois o vocacionado não foi presenteado com o dom da total incolumidade. Viver com Deus e seguir os seus planos não significa receber privilégios, mas correr os riscos de ter sua vida em constante situação de morte.

\footnotetext{
50 "Aquele que mostrou decisão e coragem em defender o fraco do agressor é mandado de volta ao faraó e aos hebreus" com a autoridade de Deus (GRENZER, 2004, p. 47), que se coloca diante de Moisés como opositor para que Moisés aprenda a confiar também em sua presença através da mulher, isto é, de quem, humanamente dizendo, é considerado mais fraco ainda, mas não recua frente aos desígnios de Deus.

${ }^{51}$ Cf. RÖMER, 1994, p. 8.
} 
Ao lado de Moisés, outros personagens passaram por situações em que sua vida esteve continuamente ameaçada pelo simples fato de terem respondido ao chamado de Deus. Bastaria lembrar, que Abraão foi provado por Deus, a fim de que aprendesse a sacrificar a sua paternidade na oferta de seu filho Isaac (Gn 22). Elias que, após a sua vitória sobre a idolatria, colocando a aliança de Deus com seu povo acima de todas as coisas, teve que fugir para salvar a sua vida da fúria de Jezabel (1Rs 19). Oseias que, para deflagrar os erros do seu povo e fazê-lo conhecer o amor incondicional de Deus, contraiu matrimonio com uma mulher infiel (Os 1,2-3,5). Jeremias que, por não resistir ao chamado de Deus, pagou duramente o preço da sua fidelidade com muitos sofrimentos, não tendo direito, por exemplo, a ter uma esposa e a participar de festas (Jr 16). Ezequiel que, para servir a Deus como sinal, além de ver sua amada esposa morrer, foi proibido de fazer luto por ela (Ez 24,16-27). Os quatro cânticos do servo sofredor de YHWH também confirmam o que significa aceitar sobre si a dor do serviço vicário e expiatório (Is 42,1-9; 49,1-6; 50,4-11; 52,13-52,12).

Séfora é, como muitas mulheres na Bíblia, agentes de salvação tanto para o antigo Israel, como para os outros povos e, com elas, se encontra o ponto de mutação ou de recondução da história ao seu curso salvífico. Bastaria, a título de exemplo, lembrar de Rute e do seu importante papel, ao lado de Noemi. Ela abriu a estrada que levou o antigo Israel a ter Davi não somente como rei, mas como fundamento do messianismo. ${ }^{52}$ Este alcançou o seu máximo significado no mistério da encarnação do Verbo Divino, Jesus de Nazaré: o Filho de Davi que tem misericórdia de todos os que vivem à margem da ortodoxia religiosa; de todos os que ainda não encontraram e não assumiram o seu espaço na vida sócio-pastoral.

Qualquer texto bíblico possui destinatários concretos, envolvendo vivências, vicissitudes, problemas, interesses e necessidades pessoais e comunitárias. Em outras palavras, os textos querem dar respostas aos seus destinatários. Todos os textos, porém, foram lidos, relidos, reinterpretados e aplicados a novos destinatários, que se encontravam em diferentes situações e em novos contextos. Isto permite que estas

${ }^{52}$ Cf. FERNANDES, 2012, p. 105-108. 
considerações finais fiquem em aberto, augurando que o conhecimento de Deus e a perícia de Séfora ajudem a compreender que cada vocação e missão, na dinâmica da fé, não estão isentas de problemas, obstáculos e dificuldades, mas servem para fortalecer a fé e a esperança na concretização dos planos de Deus na vida de cada ser humano, pois Ele é o maior interessado na sua liberdade e salvação.

\section{Referências bibliográficas}

ALONSO SCHÖKEL, L. Dicionário Bíblico Hebraico-Português. São Paulo: Paulus, 1997.

AUZOU, G. Dalla servitù al servizio. Il libro dell'Esodo. Bologna: EDB, 2008.

CHILDS, B. S. El Libro del Éxodo. Comentario crítico y teológico. Estella: Verbo Divino, 2003.

COATS, G. W. Exodus 1-18 [vol. II A]. Michigan/Cambridge: Grand Rapids, 1999.

DERBY, J. “Why did God want to kill Moses?”. In: Jewish Bible Quarterly 18,4 (1990) p. 222-229.

DOZEMAN, T. B. Commentary on Exodus. Michigan: Grand Rapids, 2009.

EMBRY, B. "The Endangerment of Moses: Towards a New Reading of Exodus 4:24-26”. In: Vetus Testamentum 60 (2010) p. 177-196.

FANULI, A. "Il Signore cercò di far moriré Mosè” (Es 4,24-26). In: Parola, Spirito e Vita 30 (1994) p. 39-48.

FERNANDES, L. A. - GRENZER, M. Êxodo 15,22-18,27. São Paulo: Paulinas, 2011.

FERNANDES, L. A. Rute. São Paulo: Paulinas, 2012.

FRETHEIM, T. E. Exodus. Louisville: John Konx Press, 1991.

FROLOV, S. “The Hero as Bloody Bridegroom: On the Meaning and Origin of Exodus 4,26”. In: Biblica 77 (1996) p. 520-523.

GARCÍA LÓPEZ, F. Éxodo. Bilbao: Desclée De Brouwer, 2007.

GRENZER, M. O Projeto do Êxodo. São Paulo: Paulinas, 2004.

HALTER, M. Tsippora. París: Robert Laffont, 2003.

HERBST, A. "Bautismo y Circuncisión Judía. Nueva luz desde un análisis de Éxodo 4,24-26”. In: Revista Bíblica 3.4 (2004) p. 157-172.

JACOBS, A. S. "Blood will out: Jesus' Circumcision and Early Christian Readings of Exodus 4,24-26”. In: Henoch 30 (2008) p. 311-332. 
KESSLER, R. “Vocación para la libertad: el caso Moisés”. In: Pistis \& Praxis 5/2 (2013) p. 345-363.

LUCIANI, D., "Çippora (Ex 4,24-26): le petit oiseau va sortir... et il échappe encore aux inteprètes”. In: Estudios Biblicos 70 (2012) p. 159-184.

NEPI, A. Esodo [capitoli 1-15]. Introduzione e commento. Padova: Messaggero, 2002.

NOTH, M. Esodo. Brescia: Paideia, 1977.

PRIOTTO, M. Esodo. Nuova versione, introduzione e commento. Milano: Paoline, 2014.

PROPP, W. H. “That Bloody Bridegroom (Exodus IV 24-26)”. In: Vetus Testamentum 43 (1993) p. 495-518.

RAVASI, G. Esodo. Brescia: Queriniana, 2007.

RIVIERA, L. F. “El ‘Esposo Sangriento’ (Ex 4,24-26)”. In: Revista Bíblica 25 (1963) p. 129-136.

ROFÉ, A. Introduzione alla letteratura della Bibbia ebraica. 1 Pentateuco e libri storici. Brescia: Paideia, 2011.

RÖMER, T., "De l'archaïque au subversive: le cas d'Exode 4/24-26". In: Études Théologiques et Religieuses 1 (1994) p. 1-12.

SCHARBERT, J. Esodo. Milano: Morceliana, 2001.

SICRE, J. L. Josue. Estella (Navarra): Verbo Divino, 2002.

SILVA, V. Deus ouve o clamor do povo. Teologia do êxodo. São Paulo: Paulinas, 2004.

SPREAFICO, A., "Esodo: Memoria e Promessa”. In: Parole di Vita 2 (1998) p. 27-33.

SPREAFICO, A. Il Libro del Esodo. Roma: Città Nuova, 1992.

STANCARI, P. Leitura Espiritual do Êxodo. São Paulo: Loyola, 1987.

WYATT, N. "Circumcision and Circumstance: Male Genital Mutilation in Ancient Israel and Ugarit'. In: Journal for the Study of the Old Testament 33.4 (2009) p. 405-431.

Recebido em: 03/07/2015

Aprovado em: 26/09/2015 